\title{
Reproductive plasticity in Petrolisthes armatus (Anomura, Porcellanidae): a comparison between a Pacific and an Atlantic population
}

\author{
Ingo S. Wehrtmann - Ivana Miranda • \\ Claudia A. Lizana-Moreno - Patricio Hernáez • \\ Vera Barrantes-Echandi • Fernando L. Mantelatto
}

Received: 31 August 2010/Revised: 9 February 2011/Accepted: 10 February 2011/Published online: 4 March 2011

(C) Springer-Verlag and AWI 2011

\begin{abstract}
The porcellanid crab Petrolisthes armatus, with a known geographic distribution covering a wide range of latitudes, was selected to conduct a comparative study on egg production and reproductive output between two populations from Pacific and Atlantic coasts. Ovigerous females were collected between September and November 2005 in Punta Morales, Pacific coast of Costa Rica $(n=137)$ and from March 2005 to July 2006 in Araçá region, São Paulo, Brazil $(n=46)$. The mean size of females was statistically different between both populations with larger females from Brazil than Costa Rica (7.9 \pm 1.31 and $6.6 \pm 0.95 \mathrm{~mm} \mathrm{CW}$, respectively). Likewise, egg production was significantly different in both populations and started in Pacific Costa Rica at a smaller female size than in Brazil. Specimens from Pacific Costa Rica produced roughly three times more eggs than equally sized females from Brazil, while newly extruded embryos were larger in Brazil than in Costa Rica $\left(0.045\right.$ and $0.039 \mathrm{~mm}^{3}$,
\end{abstract}

Communicated by H.-D. Franke.

I. S. Wehrtmann $(\bowtie) \cdot$ P. Hernáez

Unidad de Investigación Pesquera y Acuicultura

(UNIP) of the Centro de Investigación en Ciencias

del Mar y Limnología (CIMAR),

Universidad de Costa Rica,

2060 San Pedro-San José, Costa Rica

e-mail: ingowehrtmann@gmx.de

I. S. Wehrtmann · C. A. Lizana-Moreno · V. Barrantes-Echandi Escuela de Biología, Universidad de Costa Rica,

2060 San Pedro-San José, Costa Rica

C. A. Lizana-Moreno

e-mail: claulizana@gmail.com

V. Barrantes-Echandi

e-mail: vera.barrantes@gmail.com respectively). Egg volume increased during embryogenesis by 112.8 and $164.5 \%$ in Costa Rican and Brazilian populations, respectively. The egg water content increased steadily in both populations; however, eggs produced in Brazil contained always more water than those from the same developmental stage in Costa Rica. Average reproductive output (based on dry weight) was substantially lower in Brazil (0.031) than in Costa Rica (0.065). Our results confirm an impressive intraspecific plasticity of reproductive features in an intertidal decapod. The observed phenotypical variability might be related to local environmental conditions as well as to the location of the studied population concerning its geographic range of distribution.

Keywords Porcellanid crabs · Fecundity .

Reproductive output - Interpopulational variability .

Costa Rica $\cdot$ Brazil 


\section{Introduction}

Decapod crustaceans are typically characterized by having a complex life cycle with planktonic larvae. These crustaceans display a broad range of adaptations and strategies to reproduce and survive successfully in a variety of different habitats, which have made them the subject of more published papers than all other crustaceans groups combined (Martin and Davis 2001).

Reproduction is one of the most important life-history features of all organisms. The various reproductive patterns are considered to be strategic adaptations to optimize lifetime fitness (Hadfield and Strathmann 1996; Yoshino et al. 2002). Comparative studies of decapod species known to occur over a wide geographic range can provide valuable information on the development of intraspecific adaptations to different environmental conditions (Wehrtmann and Kattner 1998; Mantelatto et al. 2010; Terossi et al. 2010a). However, the number of available studies regarding this subject is still limited, which hinders the development of a more complete understanding of the evolution of life-cycle strategies in this highly diverse group of crustaceans (Garcia and Mantelatto 2001). Some studies demonstrated intraspecific differences along latitudinal gradients in the reproductive biology of decapods, including anomuran species (Jones and Simons 1983; Clarke 1987; Wehrtmann and Kattner 1998; Hernáez 2001; Lardies and Wehrtmann 2001; Brante et al. 2003; Castilho et al. 2007; Terossi et al. 2010b). The reasons for the latitudinal cline in reproductive features of marine invertebrates are still under discussion (Clarke 1992, 1993; Gallardo and Penchaszadeh 2001).

Interpopulational variability among decapods, however, cannot always be explained by latitudinal temperature gradients. Intraspecific variation of life-history trades may be the consequence of regionally varying environmental conditions, and factors such as salinity, photoperiod, and food availability may be responsible for interpopulational variability in the reproductive biology of decapods (Kyomo 2000; Ituarte et al. 2006; Bas et al. 2007; Silva et al. 2009).

Porcellanid crabs (Family Porcellanidae Haworth, 1825) form an important component of many intertidal and shallow water crustacean fauna. Currently, there are about 279 valid species partitioned among 30 genera, primarily distributed in tropical and subtropical zones (Rodríguez et al. 2005; Osawa and MacLaughlin 2010). The genus Petrolisthes Stimpson, 1858 comprises over 100 species and is the largest of the family Porcellanidae (Haig 1960; Stillman and Reeb 2001; Rodríguez et al. 2005; Osawa and MacLaughlin 2010).

The porcellanid crab Petrolisthes armatus (Gibbes, 1850) represents an ideal candidate to study the evolution of environmental adaptations, because its known distribution covers wide ranges on both the Atlantic and the Pacific coasts (Melo 1999; Stillman and Reeb 2001): western Atlantic
Ocean-North Carolina to Florida, Gulf of Mexico, Antilles, Venezuela, Panama, Colombia, and Brazil; eastern Atlantic Ocean-from Senegal to Angola, Ascension Island; and eastern Pacific Ocean (Gulf of California, Costa Rica, Galapagos Island, and Peru). With the exception of some scattered data on egg production of $P$. armatus (Reid and Corey 1991), a morphological comparison of its larvae from both sides of the Isthmus (Gore 1972), and a genetic and morphological comparison among selected populations from eastern Pacific and western Atlantic (Mantelatto et al. 2011), there is no published information available which compares reproductive features of any porcellanid species from Atlantic and Pacific.

We studied reproductive aspects of $P$. armatus from the eastern tropical Pacific (Costa Rica) and the western Atlantic (Brazil). Genetic analysis carried out to access the taxonomic status and the genetic variability among Petrolisthes armatus from Costa Rica and Brazil confirmed that both populations studied here belong to the same species (Mantelatto et al. 2011). Our findings regarding fecundity (number and volume of eggs) and reproductive output may contribute to the discussion about the underlying factors for the development of interpopulational variability in species with a wide geographic range.

\section{Materials and methods}

\section{Collection and analysis of specimens}

In Costa Rica, the collection site was the rocky intertidal area of Playa Blanca at Punta Morales $\left(10^{\circ} 05^{\prime} \mathrm{N}, 84^{\circ} 57^{\prime} \mathrm{W}\right)$, located on the eastern shore of the Gulf of Nicoya, Pacific. Monthly sampling was carried out by hand at low tide from September to December 2005. In Brazil, the porcellanid crabs were collected by hand during the daytime by two persons, at 2-month intervals from March 2005 to July 2006, at low tide along the rocky shore areas of the Araçá region $\left(23^{\circ} 48^{\prime} \mathrm{S}, 45^{\circ} 24^{\prime} \mathrm{W}\right)$, São Sebastião, state of São Paulo. The collected animals were preserved in ethyl alcohol (70-90\%) for subsequent laboratory analysis. Each ovigerous female was weighed (female wet weight), and the carapace width $(\mathrm{CW})$ was measured under a light stereomicroscope equipped with a calibrated ocular micrometer and camera lucida and/or using a caliper vernier $(0.01 \mathrm{~mm})$. Additionally, we measured the water temperature and salinity during our study period.

\section{Egg production}

The entire egg mass was carefully separated from each ovigerous female and mounted under a light stereomicroscope. Egg development was classified into three stages 
according to the criteria proposed by Wehrtmann (1990) and Mantelatto and Garcia (1999) modified from Boolootian et al. (1959). Eggs were counted under a light stereomicroscope. Egg length and width were measured from 10 to 15 eggs per female to calculate the egg volume $\left(\mathrm{mm}^{3}\right)$ using the formula for oblate spheroids $\mathrm{EV}=1 / 6$ $\left(\mathrm{a} \times \mathrm{b}^{2} \times \pi\right)$, where " $\mathrm{a}$ " represents length, and " $\mathrm{b}$ " width (Turner and Lawrence 1979). Egg production (fecundity) was expressed as clutch size of females with recently extruded embryos (Stage I) to minimize errors related to egg loss during incubation. Possible egg mortality (expressed in percentage) was estimated by comparing the difference of average total egg numbers between successive embryonic stages under the assumption that females carrying embryos in Stage I did not suffer egg loss prior to counts (Lardies and Wehrtmann 1996; Iossi et al. 2005). In order to evaluate possible differences between egg production in both populations, an analysis of covariance (ANCOVA; Zar 1999) was applied to the slopes for the relationship between egg number and body size.

Size frequency distribution was compared between both populations using a correlation coefficient of Spearman (Zar 1999). The number of individuals (percentage of the total of individuals per size class) was obtained for each study site; subsequently, the value of each size class was compared between the two populations studied herein.

\section{Reproductive output}

Only females with recently produced eggs (Stage I) were included in this analysis. The removed and counted eggs per female were weighed to obtain the total wet mass. Subsequently, the embryos were dried for $48 \mathrm{~h}$ at $60^{\circ} \mathrm{C}$ and weighed with an analytic balance $( \pm 0.01 \mathrm{mg})$ to obtain dry mass. The estimation of the water content of eggs was based upon the difference between wet and dry mass. The same methods were applied for the females, which were dried for $60 \mathrm{~h}$ (see Lardies and Wehrtmann 1996; Hernáez and Palma 2003). We calculated the reproductive output (RO) according to the formula provided by Clarke et al. (1991): weight of total egg mass of the female/weight of the female. RO values are based upon the dry mass of both females and egg mass of $P$. armatus. Energy investment in egg production was compared between both populations by a nonparametric Mann-Whitney $U$-test $(P>0.05)$.

\section{Results}

Environmental conditions

Temperature varied during the study period in Costa Rica between 28.4 and $30.9^{\circ} \mathrm{C}$ (average $29.7 \pm 1.77^{\circ} \mathrm{C}$ ), and the average salinity was $27.4 \pm 0.85 \mathrm{ppt}$, ranging from 26.8 to 28.0 ppt. In Brazil, highest and lowest temperatures were measured in September $\left(26^{\circ} \mathrm{C}\right)$ and November $\left(22^{\circ} \mathrm{C}\right)$, respectively, with an average value of $24.0 \pm 2.8^{\circ} \mathrm{C}$. Salinity fluctuated between 33 and 34 ppt (average $33.5 \pm 0.70 \mathrm{ppt})$.

Ovigerous females

In Costa Rica, a total of 137 ovigerous females were analyzed. Average size was $6.6 \pm 0.95 \mathrm{~mm} \mathrm{CW}$, and the smallest and largest egg-bearing female measured 4.6 and $9.7 \mathrm{~mm} \mathrm{CW}$, respectively. Most individuals ( $88.3 \%$ of total number of specimens) were in the range from 5.1 to 8.0 $\mathrm{CW}$, and $8.0 \%$ of all ovigerous females measured between 8.1 and $9.7 \mathrm{~mm} \mathrm{CW}$ (Fig. 1).

In Brazil, the size of ovigerous females $(n=46)$ ranged from 5.4 to $10.0 \mathrm{~mm} \mathrm{CW}$, and the average size was $7.9 \pm 1.31 \mathrm{~mm} \mathrm{CW}$. Specimens in the size range between 5.1 and $8.0 \mathrm{~mm} \mathrm{CW}(n=29)$ comprised $63.0 \%$ of all ovigerous females collected by us, and 17 individuals (37.0\% of total number of specimens) were in the size group of 8.1-10.0 mm CW (Fig. 1).

Body size was statistically different between the two populations $(t$-test $=1.90, P<0.001)$. Moreover, the comparison of both populations indicated significant differences (Spearman test $R_{s}=-0.17, P>0.05$ ) between the size frequency distribution of ovigerous females, which started to produce eggs in Costa Rica at smaller sizes than in the Brazilian population (Fig. 1). However, egg-bearing

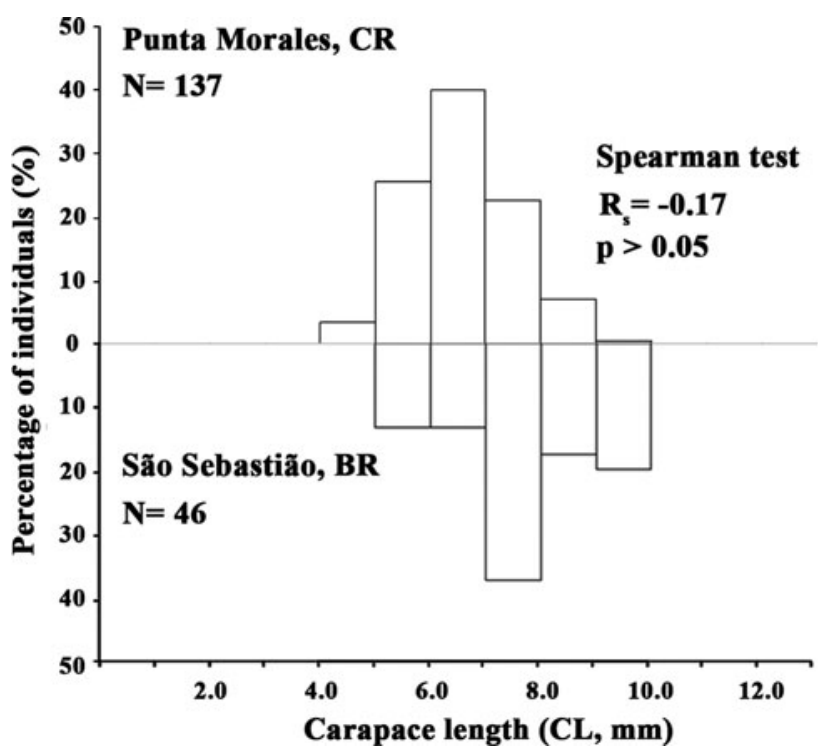

Fig. 1 Petrolisthes armatus. Carapace width frequency distribution of ovigerous females collected in Pacific Costa Rica $(n=137)$ and Brazil $(n=46)$. Spearman test indicated significant differences $(P<0.05)$ between population structures of Punta Morales (Costa Rica: CR) and São Sebastião (Brazil: BR) 
females attained a similar maximum size in both populations of Costa Rica and Brazil (Fig. 1).

Egg production

Fecundity of females collected in Costa Rica varied between 108 and 1,143 eggs $(n=137)$. Average number of recently produced eggs (Stage I) was 438 and decreased continuously to 276 eggs in Stage III (Table 1). Females with newly extruded embryos were more abundant $(55.5 \%$ of all ovigerous females) than females with more developed embryos (Stage II: 21.9\%; Stage III: 22.6\%). Egg production increased significantly with female size (Spearman test $R_{s}=0.68, P<0.01$ ): the egg number of the largest females (8.1-9.0 mm CW; $n=4: 760$ eggs; 9.1-10.0 mm CW; $n=1: 720$ eggs) was roughly 4.5 times higher than that in the group of the smallest individuals (4.1-5.0 mm CW; $n=2: 172$ eggs). During the incubation period, females lost on average $37.0 \%$ of their initially produced embryos (ANCOVA, $P<0.01$ ); egg loss was more pronounced during Stages I and II (27.5\%) than during the more advanced Stages II and III (12.9\%).

Mean volume of eggs from the Costa Rican population increased from $0.039 \mathrm{~mm}^{3}$ (Stage I) to $0.083 \mathrm{~mm}^{3}$ at the end of the embryogenesis (Stage III), which represents an increase of $112.8 \%$ during the incubation period (Table 1). Mean egg volumes of all developmental stages were statistically significantly different (ANCOVA; $P<0.01$; Tukey test; $P<0.01)$. Females of the smallest size group (4.1-5.0 mm CW) produced on average Stage I eggs that were $14.3 \%$ larger $\left(0.042 \mathrm{~mm}^{3}\right)$ than those extruded by large-sized females $\left(8.1-9.0 \mathrm{~mm} \quad \mathrm{CW} ; \quad 0.036 \mathrm{~mm}^{3}\right)$ (Table 2).

In Brazil, fecundity of females $(n=46)$ ranged from 12 to 665 eggs. Average number of eggs was highest in Stage I (252 eggs) and decreased to 136 eggs in Stage III (Table 1). During the incubation period, females lost a total of $45.9 \%$ of their initially extruded eggs (ANCOVA,

Table 1 Petrolisthes armatus; Fecundity and egg size variation in the three developmental stages of embryogenesis of females collected in Pacific Costa Rica and Brazil

\begin{tabular}{|c|c|c|c|c|c|}
\hline & \multirow[t]{2}{*}{$N$} & \multicolumn{2}{|l|}{ Fecundity } & \multicolumn{2}{|c|}{ Egg volume $\left(\mathrm{mm}^{3}\right)$} \\
\hline & & Range & Mean \pm SD & Range & Mean \pm SD \\
\hline \multicolumn{6}{|c|}{ Punta Morales, Costa Rica } \\
\hline Stage I & 76 & $124-1,143$ & $438 \pm 219.6$ & $0.026-0.070$ & $0.039 \pm 0.0102$ \\
\hline Stage II & 30 & $115-620$ & $318 \pm 117.6$ & $0.026-0.107$ & $0.062 \pm 0.0225$ \\
\hline Stage III & 31 & $108-550$ & $276 \pm 143.1$ & $0.028-0.122$ & $0.083 \pm 0.0266$ \\
\hline \multicolumn{6}{|c|}{ São Sebastião, Brazil } \\
\hline Stage I & 19 & $31-665$ & $252 \pm 184.0$ & $0.030-0.070$ & $0.045 \pm 0.0112$ \\
\hline Stage II & 15 & $27-525$ & $194 \pm 153.6$ & $0.050-0.110$ & $0.073 \pm 0.0180$ \\
\hline Stage III & 12 & $12-512$ & $136 \pm 178.6$ & $0.060-0.190$ & $0.118 \pm 0.0374$ \\
\hline
\end{tabular}

Table 2 Petrolisthes armatus; average fecundity (number of eggs $\pm \mathrm{SD}$; Stage I) and egg volume $\left(\mathrm{mm}^{3}\right)$ per size class $(\mathrm{CW}=$ carapace width), comparing the populations studied in Pacific Costa Rica and Brazil

\begin{tabular}{lrll}
\hline Size class $(\mathrm{CW} \mathrm{mm})$ & \multicolumn{1}{l}{$n$} & \multicolumn{1}{l}{ Fecundity } & \multicolumn{1}{l}{ Volume } \\
\hline Punta Morales, Costa Rica & & \\
$4.1-5.0$ & 2 & $172 \pm 11.3$ & $0.042 \pm 0.0197$ \\
$5.1-6.0$ & 20 & $239 \pm 57.1$ & $0.038 \pm 0.0091$ \\
$6.1-7.0$ & 26 & $408 \pm 101.5$ & $0.039 \pm 0.0105$ \\
$7.1-8.0$ & 23 & $622 \pm 206.1$ & $0.038 \pm 0.0094$ \\
$8.1-9.0$ & 4 & $760 \pm 310.2$ & $0.036 \pm 0.0076$ \\
$9.1-10.0$ & 0 & & \\
Total & 75 & $438 \pm 219.6$ & $0.039 \pm 0.0102$ \\
São Sebastião, Brazil & & & \\
$4.1-5.0$ & 0 & - & - \\
$5.1-6.0$ & 3 & $53 \pm 33.0$ & $0.037 \pm 0.0058$ \\
$6.1-7.0$ & 0 & - & - \\
$7.1-8.0$ & 7 & $216 \pm 125.7$ & $0.046 \pm 0.0127$ \\
$8.1-9.0$ & 4 & $269 \pm 156.1$ & $0.040 \pm 0.0115$ \\
$9.1-10.0$ & 5 & $408 \pm 216.6$ & $0.052 \pm 0.0084$ \\
Total & 19 & $252 \pm 184.0$ & $0.057 \pm 0.0400$ \\
\hline
\end{tabular}

$P>0.05)$. Females bearing recently produced eggs were more abundant $(41.3 \%$ of all ovigerous females) than females with eggs in Stage II (32.6\%) and Stage III $(26.1 \%)$. Egg production increased significantly with female size (Table 2, Spearman test $R_{s}=0.70, P<0.01$ ).

The egg volume was statistically different throughout embryonic development (ANCOVA; $P<0.01$ ), inclusive when it was compared among all stages of development (Tukey test; $P<0.05$ ). Mean egg volume increased from $0.045 \mathrm{~mm}^{3}$ (Stage I) to $0.118 \mathrm{~mm}^{3}$ at the end of the embryogenesis (Stage III) (Table 1), representing a volume increase of $162.2 \%$ during the embryogenesis.

In both populations, egg production increased significantly with female size. However, slopes were statistically

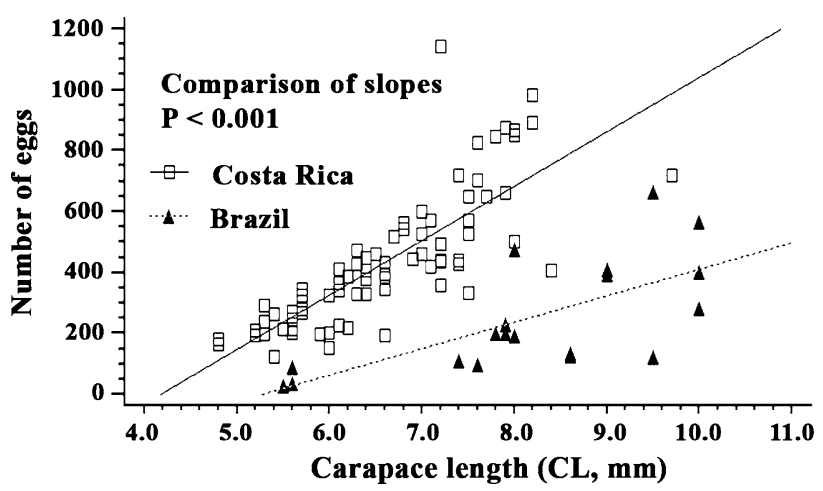

Fig. 2 Egg production in Petrolisthes armatus from Costa Rica (Pacific Ocean) and Brazil (Atlantic Ocean), with a comparison of slopes between both populations 
different (ANCOVA; $P<0.001$, Fig. 2), indicating that females of the same size produced significantly more eggs in Costa Rica than in Brazil.

\section{Egg composition}

In Costa Rica, average WW and DW of Stage I eggs were 25.85 and $12.09 \mu \mathrm{g}$, respectively, toward the end of the incubation period (Stage III), average WW increased to an average of $37.24 \mu \mathrm{g}$, while average DW dropped to $10.16 \mu \mathrm{g}$ (Table 3.) The water content of the eggs increased during embryogenesis from 53.2 to $72.7 \%$.

In Brazil, average WW increased from $93.14 \mu \mathrm{g}$ (Stage I) to $262.51 \mu \mathrm{g}$ (Stage III). In contrast, DW increased from $15.11 \mu \mathrm{g}$ (Stage I) to $16.05 \mu \mathrm{g}$ in Stage III; similarly, water content increased during the incubation period (Stage I: 83.8\%, Stage III: 93.9\%) (Table 3).

\section{Reproductive output}

The average RO (based on DW) of ovigerous females collected in Costa Rica and Brazil was $0.065 \pm 0.0154$ (from 0.031 to 0.096 ) and $0.031 \pm 0.0209$ (from 0.003 to 0.065), respectively. Energy investment in egg production was significantly different between both populations (Mann-Whitney $U$-test; $z=1.96 ; P<0.001$ ). However, there was no statistically significant relation between RO and female size for individuals collected in Costa Rica and Brazil (Spearman test; Costa Rica: $r_{s}=-0.14 ; P>0.05$; Brazil: $\left.r_{s}=-0.34 ; P>0.05\right)$.

\section{Discussion}

The porcellanid crab $P$. armatus reproduces continuously in both study sites (Costa Rica: Díaz-Ferguson and VargasZamora 2001; Brazil: Oliveira and Masunari 1995; Miranda and Mantelatto 2009). Therefore, a concentrated effort to collect females during a relatively reduced time period is an adequate method to obtain representative data regarding reproductive features (Litulo et al. 2005).

The number of eggs carried by $P$. armatus was in the range of published results for the same species collected in Florida, U.S.A., and Panama: according to Reid and Corey (1991), mean number of early-staged eggs was 330, which is relatively close to our value for the Brazilian population (252 eggs; Table 1), but $25 \%$ lower than the mean number of Stage I eggs from the Costa Rican population. The average egg number value provided by Reid and Corey (1991) was probably based upon all specimens analyzed by them $(n=30)$, and thus, it is not feasible to distinguish between fecundity of populations from Florida and Panama studied by these authors. Compared with other species of the same genus (Table 4), egg production of $P$. armatus is above average, which might be explained by the small volume of their eggs; only $P$. tuberculatus produces more eggs, but this species is substantially larger than $P$. armatus (Table 4).

Egg production started in Pacific Costa Rica at a smaller female size than in Brazil (Fig. 1). On the other hand, ovigerous females collected in Brazil reached larger sizes than those from Pacific Costa Rica. The observed shift toward larger egg-bearing females in Brazil might be related to environmental factors, especially temperature: average temperature in Pacific Costa Rica was substantially higher than in Brazil $\left(29.7^{\circ} \mathrm{C}\right.$ vs. $24.0^{\circ} \mathrm{C}$, respectively). In accordance with our findings, the results of several intraspecific studies demonstrated that reproduction of decapods started at smaller sizes in populations in warmer habitats (lower latitudes) compared with those living in cooler (higher latitudes) environments (Jones and Simons 1983; Hines 1989; Lardies and Castilla 2001; Lardies and Wehrtmann 2001; Brante et al. 2003; Bas et al. 2007; Castilho et al. 2007). The fact that temperature has been recognized to stimulate early ovarian development (Kinne 1970; Annala et al. 1980; Armitage and Landau 1982; Nelson

Table 3 Petrolisthes armatus; wet weight (WW), dry weight (DW), and water content of eggs during embryogenesis (Stage I-III), comparing populations in Pacific Costa Rica and Brazil

\begin{tabular}{|c|c|c|c|c|c|c|c|c|c|}
\hline & \multicolumn{3}{|l|}{ Stage I } & \multicolumn{3}{|l|}{ Stage II } & \multicolumn{3}{|l|}{ Stage III } \\
\hline & $\mu \mathrm{g} \pm \mathrm{SD}$ & $\%$ & $n$ & $\mu \mathrm{g} \pm \mathrm{SD}$ & $\%$ & $n$ & $\mu \mathrm{g} \pm \mathrm{SD}$ & $\%$ & $n$ \\
\hline \multicolumn{10}{|c|}{ Punta Morales, Pacific Costa Rica } \\
\hline WW & $25.85 \pm 9.322$ & - & 74 & $23.68 \pm 10.193$ & - & 20 & $37.24 \pm 16.541$ & - & 18 \\
\hline DW & $12.09 \pm 1.626$ & - & 74 & $10.72 \pm 1.462$ & - & 20 & $10.16 \pm 2.137$ & - & 18 \\
\hline Water content & $13.76 \pm 8.602$ & 53.2 & 74 & $12.96 \pm 9.968$ & 54.7 & 20 & $27.08 \pm 16.282$ & 72.7 & 18 \\
\hline \multicolumn{10}{|c|}{ São Sebastião, Brazil } \\
\hline WW & $93.14 \pm 67.697$ & - & 19 & $116.79 \pm 45.769$ & - & 15 & $262.51 \pm 153.349$ & - & 12 \\
\hline DW & $15.11 \pm 7.003$ & - & 19 & $16.20 \pm 11.679$ & - & 15 & $16.05 \pm 12.609$ & - & 12 \\
\hline Water content & $78.03+63.720$ & 83.8 & 19 & $100.59 \pm 43.761$ & 86.1 & 15 & $246.46 \pm 147.099$ & 93.9 & 12 \\
\hline
\end{tabular}


Table 4 Egg production, volume of recently extruded eggs, and female size of different Petrolisthes species

\begin{tabular}{llllll}
\hline Species of Petrolisthes & $\begin{array}{l}\text { Female size } \\
\text { (CL; mm) }\end{array}$ & $\begin{array}{l}\text { Egg number } \\
\text { (Min.-Max.) }\end{array}$ & $\begin{array}{l}\text { Average egg } \\
\text { number }\end{array}$ & $\begin{array}{l}\text { Egg volume } \\
\left(\mathrm{mm}^{3}\right)\end{array}$ & Reference \\
\hline P. armatus (Florida, Panama) & $3.8-9.2$ & n.a. & 330 & 0.050 & Reid and Corey 1991 \\
P. armatus (Pacific Costa Rica) & $4.6-9.7$ & $108-1,143$ & 429 & 0.039 & Present study \\
P. armatus (Brazil) & $5.4-10.0$ & $31-665$ & 252 & 0.045 & Present study \\
P. granulosus & $4.7-9.0$ & $40-225$ & 115 & 0.155 & Hernáez and Palma 2003 \\
P. haigae & $3.4-6.8$ & n.a. & 247 & 0.121 & Reid and Corey 1991 \\
P. laevigatus & $8.5-18.2$ & $56-1,141$ & 364 & 0.226 & Lardies and Wehrtmann 1996 \\
P. politus & $4.5-12.4$ & $2-999$ & 263 & n.a. & Scelzo 1985 \\
P. tuberculatus (central Chile) & $8.2-27.7$ & $174-5,316$ & n.a. & n.a. & Antezana et al. 1965 \\
P. tuberculatus (northern Chile) & $8.8-13.5$ & $27-537$ & 213 & 0.103 & Hernáez and Palma 2003 \\
P. violaceus & $7.4-16.6$ & $16-325$ & 104 & 0.189 & Hernáez and Pinheiro 2001 \\
P. zacae & $4.8-7.0$ & n.a. & 212 & 0.124 & Reid and Corey 1991
\end{tabular}

n.a. information not available, $C L$ carapace length

et al. 1988) may explain the earlier onset of egg production in the Costa Rican population (Fig. 1).

In both populations studied herein, fecundity increased with female size (Fig. 2). Such a pattern has been described previously for a number of other decapods (e.g., Hines 1982; Lardies and Castilla 2001; Lardies and Wehrtmann 2001; Pavanelli et al. 2010). However, specimens from Pacific Costa Rica produced roughly three times more eggs when compared to equally sized females from Brazil (Fig. 2; Table 2). These differences are closely related to the egg volume, since both newly extruded embryos (Stage I: $15 \%$ larger) and eggs close to hatching (Stage III: $42 \%$ larger) were considerably larger in Brazil. Thus, females of P. armatus in lower latitudes (Pacific Costa Rica) produced substantially more and smaller eggs than those in higher latitudes (Brazil). These findings resemble latitudinal differences in egg production observed in other decapods (Lonsdale and Levinton 1985; Wehrtmann and Kattner 1998; Lardies and Castilla 2001; Lardies and Wehrtmann 2001; Brante et al. 2003; Bas et al. 2007; Terossi et al. 2010b) and are in accordance with the idea that one species can produce a large quantity of small eggs or a lesser quantity of large eggs (Christiansen and Fenchel 1979; Wägele 1987; Giangrande et al. 1994). However, this hypothesis is based upon the assumption that in both scenarios the species is investing the same amount of energy in egg production.

The Costa Rican population of $P$. armatus inverted on average more than double the amount of energy for egg production (0.065) as females in Brazil (0.031). According to these results, the aforementioned assumption that the female energy investment in reproduction (reproductive output: RO; Clarke et al. 1991) is the same in both population needs to be rejected. The underlying reasons for these differences are unknown, but $P$. armatus in São Sebastião is living close to the southern limit of its geographic distribution. This subtropical area in Brazil is known as a biogeographic boundary, where the geographic distribution of several tropical species ends and that of temperate and subantarctic species begins (Melo 1985; Costa et al. 2000). The study of Sorte and Hofmann (2004) addressed the role of stress in setting the species' range limits; their results with the intertidal dogwhelk Nucella canaliculata clearly demonstrated that individuals were less abundant and more stressed at its southern range edge than at the range center. In accordance with these observations, several authors mention that environmental conditions at the border of a species' distribution are suboptimal, and consequently limiting the individual success (Brown 1984; Gilman 2005, Rivadeneira et al. 2010). Thus, it might be speculated that females of $P$. armatus living close to its southern range edge (Brazil) invert less energy in reproduction and more energy to cope with the environmentally related stress conditions than specimens in Pacific Costa Rica, living closer to the center of its geographic distribution and possibly close to optimum conditions. Therefore, we might expect a lower $\mathrm{RO}$ in areas close to the edges of the geographic distribution of the species, and this assumption is clearly supported by our data. Further studies, however, are needed to corroborate this tendency, to estimate energy allocation for growth and reproduction in $P$. armatus populations across its entire geographic range, and to compare the results with those obtained by us from the Costa Rican and Brazilian population.

Brood weight in decapods is constrained generally to about $10 \%$ of female body weight, ranging from 3 to $22 \%$ (Hines 1991, 1992). The RO values for the Pacific Costa Rican $(6.5 \%)$ and Brazilian (3.1\%) populations of $P$. armatus are within this range. Temperate porcellanid crabs seem to have RO values around or below 5\% (Lardies and Wehrtmann 
1996; Hernáez 2001; Hernáez and Palma 2003), and it is not unusual that tropical representatives of this family show RO values below $3 \%$ (IS Wehrtmann, unpubl. data). It might be speculated that the low RO for the Brazilian population, living in an environment frequently disturbed by human-produced pollutants (Vergamini and Mantelatto 2008; Miranda and Mantelatto 2009), represents a reproductive adaptation to cope with possible environment impacts.

Our data from the Costa Rica population concerning egg volume of $P$. armatus are in agreement with those reported for the same species in Florida and Panama (Table 4). According to the information published so far, $P$. armatus produces the smallest eggs of any species in the same genus: most of the other Petrolisthes species produce eggs with a volume of well above $0.100 \mathrm{~mm}^{3}$, reaching a maximum value of $0.226 \mathrm{~mm}^{3}$ in P. laevigatus (Lardies and Wehrtmann 1996).

Egg volume more than doubled during embryogenesis in both $P$. armatus populations studied here. Reported values for egg volume increase among porcellanids crabs range from $43 \%$ (Petrolisthes granulosus) to $88 \%$ (Liopetrolisthes patagonicus) (Hernáez and Palma 2003). According to Reid and Corey (1991), P. armatus from Pacific Panama exhibited a $66.9 \%$ increase in mean egg volume. These authors also indicated in the same publication a $120 \%$ egg volume increase in P. armatus. Our values are higher than those reported so far for porcellanid crabs, including other studies about $P$. armatus. However, available information refers mainly to species inhabiting temperate zones (Lardies and Wehrtmann 1996; Hernáez and Palma 2003). Thus, additional data concerning porcellanid crabs from tropical and subtropical zones are required to evaluate the hypothesis that species from these zones show a higher egg volume increase than those from temperate zones.

The physical space available for egg attachment is a limiting factor in decapods (Reid and Corey 1991; Hines 1992), and a substantial increase in egg volume during the incubation period is usually associated with egg loss during embryogenesis. Since the egg volume increase was more pronounced in the Brazilian population of $P$. armatus, it is not surprising that egg loss was also higher in this population $(45.9 \%$ versus $37.0 \%)$. These values are within the range of brood mortality reported for other decapods (from 4 to $71 \%$ Kuris 1991) and close to the values published for other porcellanid species (Lardies and Wehrtmann 1996; Hernáez and Palma 2003).

Eggs from the Brazilian population of $P$. armatus were substantially larger and heavier (WW) than those from Costa Rican specimens (Table 3). These differences are probably associated with the water content: newly extruded eggs from Brazilian females contained substantially more water than those from Costa Rican individuals (83.8 vs. $53.2 \%$, respectively), and the initial DW was also higher in
Brazilian as in the Costa Rican specimens (Table 3). In both populations, we observed a steady increase in the water content during the incubation period, which is in accordance with similar studies on decapod egg development (Lardies and Wehrtmann 1996, 1997; Wehrtmann and Kattner 1998; Wehrtmann and López 2003). The observed differences in water content in Stage I embryos in the two study areas were also evident in eggs close to hatching (93.9 versus $72.7 \%$, respectively). The value for the Brazilian population is slightly higher than the range of 60-80\% egg water content mentioned by Pandian (1970) for decapods.

We do not have a conclusive explanation for the higher water content of eggs from Brazilian females. According to Péqueux (1995), salinity is the most important factor influencing reproduction and development of crustaceans inhabiting aquatic environments subject to fluctuations. Moran and McAlister (2009) stated that salinity-driven plasticity of egg size is likely to be due simply to osmotic water uptake by eggs in low-salinity waters. This conclusion is supported by the results reported by Giménez and Anger (2001): in the estuarine crab, Neohelice granulata, females held at a lower pre-hatching salinity (15 ppt) produced larger eggs than those from crabs held at $32 \mathrm{ppt}$. In our study, however, egg water content was higher in the Brazilian population, where the salinity was substantially higher (average $33.5 \pm 0.70 \mathrm{ppt}$ ). Therefore, additional studies are necessary to determine the relation between salinity and egg size, more specifically water content of eggs.

In conclusion, our findings provide further evidence for the high interpopulational plasticity of intertidal marine decapods. Although the populations studied by us are from two different oceans with different biological-oceanographic conditions, the results presented herein corroborate partially Thorson's rule (Thorson 1950) concerning the latitudinal variation of female and egg size: in P. armatus, both parameters increased toward higher latitudes. Moreover, the fact that $P$. armatus produced more but smaller eggs in lower latitudes is in accordance to similar results obtained from other marine decapods. Independently of these differences, the RO was substantially lower in females from Brazil (Table 3), which might be related to the fact that this population lives at the southern extreme of its geographical distribution. Some intraspecific studies have demonstrated that the RO decreased toward higher latitudes (see Clarke 1987), while others reported increasing RO values toward lower latitudes (e.g., Lardies and Wehrtmann 2001). As in other interpopulational studies, latitude alone cannot explain these opposing RO trends (Berkenbusch and Rowden 2000; Bas et al. 2005, 2007), and we are convinced that local environmental conditions (such as temperature, salinity, food availability, and 
pollution) exert a significant influence on the reproductive ecology of different populations of the same species. Our results confirm the existence of a high ecological plasticity among intertidal marine decapods to adapt and reproduce under different environmental settings, which in turn may explain the wide geographic distribution of the species. There are, however, still many questions to be answered, e.g., which reproductive features of a species continue to be constant across the geographical range and throughout the variety of local environmental conditions, which aspects of the reproductive biology are adaptable to locally occurring environmental factors, and how the post-hatching success and growth patterns might affect populations inhabiting different environmental settings.

Acknowledgments FLM and ISW are grateful to the International Cooperative Project by CNPq-Brazil and CONICIT-Costa Rica (Proc. 491490/2004-6; 490353/2007-0) and the Universidad de Costa Rica (VI N ${ }^{\circ}$ 808-A6-117; VI $N^{\circ}$ 808-A9-209) for financial support for the visiting program in Brazil and Costa Rica. This work is also part of a Master's thesis by IM and was supported by a scholarship from CAPES. FLM and IM are grateful to CNPq for a research (Proc. 301359/07-5 and 302748/2010-5) and doctoral fellowships (Proc. 140677/08-9), respectively. PH is supported by a Doctoral fellowship from CAPES. The support of the Programa de Pós-Graduação em Ciências-Biologia Comparada-FFCLRP/USP and CEBIMar/USP during fieldwork and IBAMA for sampling permission in Brazil (Proc. 02027.002161/2005-88) is gratefully acknowledged. All experiments conducted in this study comply with current applicable state and federal laws. Finally, we wish to thank Paul Hanson (Universidad de Costa Rica) for revising the English and his critical comments on the manuscript.

\section{References}

Annala JH, McKoy JL, Booth D, Pike RB (1980) Size at the onset of sexual maturity in female Jasus edwardsii (Decapoda: Palinuridae) in New Zealand. New Zealand J Mar Freshwat Res 14:217-228

Antezana T, Fagetti E, López MT (1965) Observaciones bioecológicas en decápodos de Valparaíso. Rev Biol Mar 12:1-60

Armitage KB, Landau M (1982) The effects of photoperiod and temperature on growth and reproduction of Daphnia ambigua. Comp Biochem Physiol 71A:137-140

Bas C, Luppi T, Spivak E (2005) Population structure of the South American estuarine crab, Chasmagnathus granulatus (Brachyura: Varunidae) near the southern limit of its geographical distribution: comparison with northern populations. Hydrobiologia 537:217-228

Bas CC, Spivak ED, Anger K (2007) Seasonal and interpopulational variability in fecundity, egg size, and elemental composition (CHN) of eggs and larvae in a grapsoid crab, Chasmagnathus granulatus. Helgol Mar Res 61:225-237

Berkenbusch K, Rowden AA (2000) Latitudinal variation in the reproductive biology of the burrowing ghost shrimp Callianassa filholi (Decapoda: Thalassinidea). Mar Biol 136:497-504

Boolootian RA, Giese AC, Farmanfarmain A, Tucker J (1959) Reproductive cycles of five west coast crabs. Physiol Zool $32: 213-220$
Brante A, Fernandez M, Eckerle L, Mark F, Pörtner HO, Arntz W (2003) Reproductive investment in the crab Cancer setosus along a latitudinal cline: egg production, embryo losses and embryo ventilation. Mar Ecol Prog Ser 251:221-232

Brown JH (1984) On the relationship between abundance and distribution of species. Am Nat 124:255-279

Castilho AL, Costa RC, Fransozo A, Boschi EE (2007) Reproductive pattern of the South American endemic shrimp Artemesia longinaris (Decapoda: Penaeoidea), off São Paulo State, Brazil. Rev Biol Trop 55(Suppl. 1):39-48

Christiansen FB, Fenchel TM (1979) Evolution of marine invertebrate reproductive patterns. Theoret Pop Ecol 16:267-282

Clarke A (1987) Temperature, latitude and reproductive output. Mar Ecol Prog Ser 38:89-99

Clarke A (1992) Reproduction in the cold: Thorson revisited. Invert Reprod Develop 22:175-184

Clarke A (1993) Reproductive trade-offs in caridean shrimps. Funct Ecol 7:411-419

Clarke A, Hopkins C, Nilssen M (1991) Egg size and reproductive output in the deepwater prawn Pandalus borealis Krøyer, 1838. Funct Ecol 5:724-730

Costa RC, Fransozo A, Mantelatto FL, Castro RH (2000) Occurrence of shrimp species (Crustacea: Decapoda: Natantia: Penaeoidea and Caridea) in Ubatuba Bay, Ubatuba, SP, Brazil. Proc Biol Soc Wash 113:776-781

Díaz-Ferguson E, Vargas-Zamora JA (2001) Abundance of Petrolisthes armatus (Crustacea: Porcellanidae) on a tropical estuarine intertidal rocky beach, Gulf of Nicoya estuary, Costa Rica. Rev Biol Trop 49(Suppl. 2):97-101

Gallardo CS, Penchaszadeh PE (2001) Hatching mode and latitude in marine gastropods: revisiting Thorson's paradigm in the southern hemisphere. Mar Biol 138:547-552

Garcia RB, Mantelatto FL (2001) Population dynamics of the hermit crab Paguristes erythrops (Diogenidae) from Anchieta Island, southern Brazil. J Mar Biol Assoc UK 81:955-960

Giangrande A, Geraci S, Belomonte G (1994) Life-cycle and lifehistory diversity in marine invertebrates and the implications in community dynamics. Oceanogr Mar Biol Ann Rev 32:305-333

Gilman S (2005) A test of Brown's principle in the intertidal limpet Collisella scabra (Gould, 1846). J Biogeogr 32:1583-1589

Giméñez L, Anger K (2001) Relationships among salinity, egg size, embryonic development, and larval biomass in the estuarine crab Chasmagnathus granulata Dana, 1851. J Exp Mar Biol Ecol 260:241-257

Gore RH (1972) Petrolisthes armatus (Gibbes, 1850): the development under laboratory conditions of larvae from a Pacific specimen (Decapoda, Porcellanidae). Crustaceana 22:67-83

Hadfield MG, Strathmann MF (1996) Variability, flexibility and plasticity in life histories of marine invertebrates. Oceanol Acta 19:189-475

Haig J (1960) The Porcellanidae (Crustacea, Anomura) of the Eastern Pacific. Allan Hancock Pac Exped 24:1-440

Hernáez P (2001) Producción y rendimiento reproductivo en Petrolisthes granulosus (Decapoda, Anomura, Porcellanidae) en diferentes localidades del norte de Chile: una comparación latitudinal. Invest Mar Valparaíso 29:73-81

Hernáez P, Palma S (2003) Fecundidad, volumen del huevo y rendimiento reproductivo de cinco especies de porcelánidos intermareales del norte de Chile (Decapoda, Porcellanidae). Invest Mar 31:35-46

Hernáez P, Pinheiro MAA (2001) Production and reproductive output of four porcelain crab species from northern Chile. Nauplius 9:42-52

Hines AH (1982) Allomteric constraints and variables of reproductive effort in brachyuran crabs. Mar Biol 69:309-320 
Hines AH (1989) Geographic variation in size at maturity in brachyuran crabs. Bull Mar Sci 45:356-368

Hines AH (1991) Fecundity and reproductive output in nine species of Cancer crabs (Crustacea, Brachyura, Cancridae). Can J Fish Aquat Sci 48:267-275

Hines AH (1992) Constraint on reproductive output in brachyuran crabs: pinntherids test the rule. Am Zool 32:503-511

Iossi CL, Biagi R, Mantelatto FL (2005) Egg production and shell relationship of the hermit crab Pagurus brevidactylus (Anomura: Paguridae) from southern Brazil. Anim Biol 55:111-121

Ituarte RB, Bas C, Luppi TA, Spivak ED (2006) Interpopulational differences in the female reproductive cycle of the southwestern Atlantic estuarine crab Chasmagnathus granulatus Dana, 1851 (Brachyura: Grapsoidea: Varunidae). Sci Mar 70:709-718

Jones MB, Simons MJ (1983) Latitudinal variation in reproductive characteristics of a mud crab, Helice crassa (Grapsidae). Bull Mar Sci 33:656-670

Kinne O (1970) Temperature: animals-invertebrates. In: Kinne O (ed) Marine ecology, vol 1, environmental factors, part I. Wiley-Interscience, London, pp 407-514

Kuris AM (1991) A review of patterns and causes of crustacean brood mortality. In: Wenner A, Kuris A (eds) Crustacean egg production, crustacean issues, vol 7. A. A. Balkema, Rotterdam, pp 117-141

Kyomo J (2000) Intraspecific variation of reproductive strategies of the crab Sesarma intermedia: a consequence of habitat variations. Bull Mar Sci 66:157-171

Lardies MA, Castilla JC (2001) Latitudinal variation in the reproductive biology of the commensal crab Pinnaxodes chilensis (Decapoda: Pinnotheridae) along the Chilean coast. Mar Biol 139:1125-1133

Lardies MA, Wehrtmann IS (1996) Aspects of the reproductive biology of Petrolisthes laevigatus (Guérin, 1835) (Decapoda: Anomura: Porcellanidae). I. Reproductive output and chemical composition of eggs during embryonic development. Arch Fish Mar Res 43:121-135

Lardies MA, Wehrtmann IS (1997) Egg production in Betaeus emarginatus (H. Milne Edwards, 1837) (Decapoda: Alpheidae): fecundity, reproductive output and chemical composition of eggs. Ophelia 46:165-174

Lardies MA, Wehrtmann IS (2001) Latitudinal variation in the reproductive biology of Betaeus truncatus (Decapoda: Alpheidae) along the Chilean coast. Ophelia 55:55-67

Litulo C, Macia A, Mantelatto FL (2005) Fecundity and sexual maturity of the crab Macrophtalmus depressus (Brachyura: Ocypodidae) from Inhaca Island, Mozambique. Afr J Aquat Sci 30:179-183

Lonsdale DJ, Levinton J (1985) Latitudinal differentiation in embryonic duration, egg size, and newborn survival in a harpacticoid copepod. Biol Bull 168:419-431

Mantelatto FL, Garcia RB (1999) Reproductive potential of the hermit crab Calcinus tibicen (Anomura) from Ubatuba, São Paulo, Brazil. J Crust Biol 19:268-275

Mantelatto FL, Fernandes-Góes LC, Fantucci MZ, Biagi R, Pardo LM, Góes JM (2010) A comparative study of population traits between two South American populations of the striped-legged hermit crab Clibanarius vittatus. Acta Oecol 36:10-15

Mantelatto FL, Pileggi LG, Miranda I, Wehrtmann IS. (2011) Does Petrolisthes armatus (Anomura, Porcellanidae) form a species complex or are we dealing with just one widely distributed species? A comparison among American populations. Zool Stud $50(3)$

Martin JW, Davis GE (2001) An updated classification of the recent Crustacea. Sci Ser Nat Hist Mus LA County 39:1-124

Melo GAS (1985) Taxonomia e padrões distribucionais e ecológicos dos Brachyura (Crustacea, Decapoda) do litoral sudeste do Brasil. Dissertation, University of São Paulo, Brazil
Melo GAS (1999) Manual de Identificação dos Crustacea Decapoda do Litoral Brasileiro: Anomura, Thalassinidea, Palinuridea, Astacidea. Editora Plêiade, Brazil

Miranda I, Mantelatto FL (2009) Estimating population features of the anomuran crab Petrolisthes armatus (Porcellanidae) in a remaining and impacted mangrove area of western Atlantic. J Nat Hist 43:2027-2039

Moran AL, McAlister JS (2009) Egg size as a life history character of marine invertebrates: is it all it's cracked up to be? Biol Bull 216:226-242

Nelson K, Hedgecock D, Borgeson W (1988) Factors influencing egg extrusion in the American lobster (Homarus americanus). Can J Fish Aquat Sci 45:797-804

Oliveira E, Masunari S (1995) Estrutura populacional de Petrolisthes armatus (Gibbes, 1850) (Decapoda, Anomura, Porcellanidae) da Ilha do Farol, Caiobá, Paraná. Revta Bras Zool 12:355-371

Osawa M, MacLaughlin PA (2010) Annotated checklist of anomuran decapod crustaceans (exclusive of the Kiwaoidea and families Chirostylidae and Galatheidae of Galatheoidea) Part II-Porcellanidae. Raffles B Zool 23:109-129

Pandian TJ (1970) Ecophysiological studies on the developing eggs and embryos of the european lobster Homarus gammarus. Mar Biol 5:154-167

Pavanelli CAM, Mossolin EC, Mantelatto FL (2010) Maternal investment in egg production: environmental and populationspecific effects on offspring performance in the snapping shrimp Alpheus nuttingi (Schmitt, 1924) (Decapoda, Alpheidae). Anim Biol 60:237-247

Péqueux A (1995) Osmotic regulation in crustaceans. J Crust Biol $15: 1-60$

Reid DM, Corey S (1991) Comparative fecundity of decapod crustaceans, II. The fecundity of fifteen species of anomuran and brachyuran crabs. Crustaceana 61:175-189

Rivadeneira MM, Hernáez P, Baeza JA, Boltaña S, Cifuentes M, Correa C, Cuevas A, del Valle E, Hinojosa I, Ulrich N, Valdivia N, Vásquez N, Zander A, Thiel M (2010) Testing the abundantcentre hypothesis using intertidal porcelain crabs along the Chilean coast: linking abundance and life-history variation. J Biogeogr 37:486-498

Rodríguez IT, Hernández G, Felder DL (2005) Review of the western Atlantic Porcellanidae (Crustacea: Decapoda: Anomura) with new records, systematic observations, and comments on biogeography. Carib J Sci 41:544-582

Scelzo MA (1985) Biologia y morfometria del cangrejo Petrolisthes politus (Gray, 1831) (Anomura, Porcellanidae) de la Isla Cubagua, Venezuela. Bol Inst Oceanogr Oriente 24:63-74

Silva PV, Luppi TA, Spivak ED, Anger K (2009) Reproductive traits of an estuarine crab, Neohelice (= Chasmagnathus) granulata (Brachyura: Grapsoidea: Varunidae), in two contrasting habitats. Sci Mar 73:117-127

Sorte CJB, Hofmann GE (2004) Changes in latitudes, changes in aptitudes: Nucella canaliculata (Mollusca: Gastropoda) is more stressed at its range edge. Mar Ecol Prog Ser 274:263-268

Stillman JH, Reeb CA (2001) Molecular phylogeny of eastern Pacific porcelain crabs, genera Petrolisthes and Pachycheles, based on the mtDNA 16S rDNA sequence: phylogeographic and systematic implications. Mol Phylogenet Evol 19:236-245

Terossi M, Wehrtmann IS, Mantelatto FL (2010a) Interpopulational comparison of reproduction of the Atlantic shrimp Hippolyte obliquimanus (Caridea: Hippolytidae). J Crust Biol 30:571-579

Terossi M, Torati LS, Miranda I, Scelzo MA, Mantelatto FL (2010b) Comparative reproductive biology of two southwestern Atlantic populations of the hermit crab Pagurus exilis (Crustacea: Anomura: Paguridae). Mar Ecol 31:584-591

Thorson G (1950) Reproductive and larval ecology of marine bottom invertebrates. Biol Rev 25:1-45 
Turner RL, Lawrence JM (1979) Volume and composition of echinoderm eggs: implications for the use of egg size in lifehistory models. In: Stancyk WE (ed) Reproductive ecology of marine invertebrates. University South Carolina Press, Library Marine Science 9, Columbia, pp 25-40

Vergamini FG, Mantelatto FL (2008) Continuous reproduction and recruitment in the narrowback mud crab Panopeus americanus (Brachyura, Panopeidae) in a remnant human-impacted mangrove area. Invert Reprod Develop 51:1-10

Wägele JW (1987) On the reproductive biology of Ceratoserolis trilobitoides (Crustacea: Isopoda): latitudinal variation of fecundity and embryonic development. Polar Biol 7:11-24

Wehrtmann IS (1990) Notes on the distribution and reproduction of Ambidexter panamense and Palaemonetes schmitti in Pacific Costa Rica (Crustacea, Decapoda). Rev Biol Trop 38:327-329
Wehrtmann IS, Kattner G (1998) Changes in volume, biomass, and fatty acids of developing eggs in Nauticaris magellanica (Decapoda: Caridea): a latitudinal comparison. J Crust Biol 18:413-422

Wehrtmann IS, López GA (2003) Effects of temperature on the embryonic development and hatchling size of Betaeus emarginatus (Decapoda: Caridea: Alpheidae). J Nat Hist 37:2165-2178

Yoshino K, Goshima S, Nakao S (2002) Temporal reproductive patterns within a breeding season of the hermit crab Pagurus filholi: effects of crab size and shell species. Mar Biol 141:1069-1075

Zar JH (1999) Biostatistical analysis, 4th edn. Prentice Hall, Upper Saddle River, NJ 